\title{
Nothofagus pumilio forest affected by recent tephra deposition in northern Patagonia. I- Environmental traits influencing seedling growth
}

\author{
Denise Moguilevsky ${ }^{1,2}$, Natalia V. Fernández ${ }^{1,2}$, Pablo E. Cornejo ${ }^{3,4}$, Javier G. Puntieri' ${ }^{2,5}$, \\ Sonia B. Fontenla ${ }^{1}$
}

${ }^{1}$ Laboratorio de Microbiología Aplicada y Biotecnología, Centro Regional Universitario Bariloche, Universidad Nacional del Comahue and IPATEC, Quintral 1250, Bariloche, Argentina. ${ }^{2}$ Consejo Nacional de Investigaciones Cientificas y Técnicas (CONICET), Buenos Aires, Argentina. ${ }^{3}$ Departamento de Ciencias Químicas y Recursos Naturales, Scientific and Technological Bioresource Nucleus, BIOREN-UFRO, Universidad de La Frontera, P.O. Box 54-D, Temuco, Chile. ${ }^{4}$ Centro de Investigación en Micorrizas y Sustentabilidad Agroambiental, CIMYSA, Facultad de Ingeniería y Ciencias, Universidad de La Frontera, P.O. Box 54-D, Temuco, Chile. ${ }^{5}$ Instituto de Investigaciones en Recursos Naturales, Agroecología y Desarrollo Rural (IRNAD), Universidad Nacional de Río Negro, John O'Connor 181, Bariloche, Argentina. *Corresponding author: dmoguile@gmail.com

\begin{abstract}
The 2011 Puyehue-Cordón Caulle volcanic eruption left vast areas of Nothofagus pumilio forests covered by high volumes of tephra, which buried the understory. This event offered a unique opportunity to analyse the impact of recent tephra deposition and the main environmental factors affecting the growth of $N$. pumilio seedlings. To this end, three study sites were selected and sampled three years after the eruption, two with a thick tephra layer (50 $\mathrm{cm}$ ) but with different tree conditions: i) most trees alive or ii) most trees dead, and a third site, iii) with minimal tephra deposition. From each site, five $N$. pumilio 18-month-old seedlings were collected, morphometrically measured (shoot, epicotyl and main root length; shoot, epicotyl and root collar diameter), and environmental factors were also registered (light intensity, soil $\mathrm{pH}$ and conductivity, available $\mathrm{P}$, bulk and particle soil density, and porosity). The main results indicated that three years after eruption the site with tephra deposition and dead trees (the most near to the crater) had the biggest seedlings, the lowest $\mathrm{pH}$ and the highest values for available $\mathrm{P}$ and light intensity. This temporally unique geological event showed that the regeneration potentiality of $N$. pumilio is high when environmental factors allow direct incident light on a substrate with high mineral content, even when the environment has previously been subjected to a significant degree of disturbance. Given the recurrence of volcanic events in northern Patagonia, this subject merits further long-term study.
\end{abstract}

Keywords: Nothofagus pumilio, forest ecology, high-magnitude disturbance, tephra, volcanic eruption, seedling development. 


\section{Introduction}

Volcanic eruptions give rise to significant geological, ecological and social changes (Dale et al., 2005; González et al., 2014). Tephra fall is one of the major and most extensive disturbances and can be deposited several kilometres from the volcano, depending on the speed and orientation of the prevailing winds (Swanson and Major, 2005; González et al., 2014). The deposit of fine ash to gravel-sized rock debris on the soil represents a high impact modification in the ecosystem dynamics, and generates the need to understand interactions between volcanic events and biological systems (Swanson and Major, 2005; Swanson et al., 2016).

In the South and Central Andean area of Argentina and Chile volcanic eruptions are recurrent; over the last century there were 28 volcanic eruptions (González et al., 2014). In the recent vulcanological history of this area the last eruption of the Puyehue-Cordón Caulle volcanic complex (PCCVC) stands out as having a marked impact on the environment. It began in June 2011 and remained active for about a year, generating significant tephra deposits over a large area of northern Patagonia in Argentina and Chile (Villarrosa and Outes, 2013). This not only affected plant cover noticeably (Grosfeld and Puntieri, 2013; González et al., 2014; Ghermandi et al., 2015; Swanson et al., 2016), but also soil insects and microorganisms (Ferreiro et al., 2015). One of the ecosystems most severely affected by the eruption were Nothofagus forests, with large areas covered by a tephra layer of more than $40 \mathrm{~cm}$ (Villarrosa and Outes, 2013; Ghermandi et al., 2015; Swanson et al., 2016). Nothofagus pumilio (Lenga) is a deciduous endemic tree from temperate South American forests, and is one of the most important and widely distributed forestry species in Argentina and Chile (between $35^{\circ} \mathrm{S}$ and $55^{\circ} \mathrm{S}$ ). Natural regeneration of $N$. pumilio occurs from seeds and mostly takes place in open areas, since it is a semi-heliophilic species (Rebertus and Veblen,
1993; Heinemann, 2007; Martínez Pastur et al., 2007). The regeneration dynamics of $N$. pumilio forests is influenced by large-scale (avalanches, fires, winds and volcanisms) and small-scale disturbances (such as tree fall), which result in a regeneration strategy of gap dynamics (González et al., 2006; Heinemann, 2007). Therefore, its regeneration is primarily associated with disturbances of varying intensity, including volcanic events (González et al., 2006).

Volcanic plumes from the PCCVC eruption generated tephra deposits of different thicknesses, and in the region close to the Cardenal Samoré International border the tephra layer lying on the forest soil exceeded 40 $\mathrm{cm}$ in depth, significantly affecting the mortality of understory plants and adult Nothofagus trees (Montiel et al., 2016). During the first years following the PCCVC eruption, seed germination occurred directly on the thick tephra deposits, and seedling roots were not able to exploit the underlying soil (Grosfeld and Puntieri, 2013). Considering that the tephra nutrient content was low (particularly with respect to total $\mathrm{N}$ and available $\mathrm{P}$ ), and much lower than in the forest soil, there may not be enough nutrients to satisfy the requirements of the vegetation (Cremona et al., 2011). It is unknown how these factors could influence natural regeneration of dominant plant species, such as N. pumilio; therefore, the PCCVC volcanic event represents a unique opportunity to study the natural regeneration of native Nothofagus forests following a high magnitude disturbance, and could contribute to understanding the regeneration dynamics and vegetation succession of natural environments. This information is relevant in the current climate change scenario, and can be useful in the development of restoration strategies for different potentially severely affected environments. In this context, extensive research was carried out, oriented towards understanding the principal factors, both biotic and abiotic, that determine the restoration of 
temperate ecosystems such as Nothofagus forest after a catastrophic event like a volcanic eruption. As part of this research, the aim of the present study was to analyse the impact of tephra deposits and different ecological factors on the growth of $N$. pumilio seedlings. We performed the study in native $N$. pumilio forests severely affected by tephra deposition from the PCCVC eruption, and compared with a forest with a minimal tephra layer on the soil. We examined environmental parameters associated with seedling growth, such as light intensity and physicochemical characteristics of the substrates (tephra and soil).

\section{Material and Methods}

\subsection{Study area and sampling}

This study was carried out in April 2014 (three years after the last PCCVC eruption) in native $N$. pumilio forests located in northern Patagonia, with sampling sites located in Argentina and Chile (Table 1). Soils of this area are predominantly Andisols, characterized by low bulk density, a high capacity to stabilize organic low bulk density, a high capacity to stabilize organic matter, store water and an elevated total P content (Shoji et al., 1993; Mazzarino and Gobbi, 2005; Satti et al., 2007). Their main limitation is high P retention (Mazzarino and Gobbi, 2005; Satti et al., 2007; Cornejo et al., 2017). The climate of this region is characterized by an average annual temperature of $9.5^{\circ} \mathrm{C}$ and mean annual precipitation ranging from 3000 in the west to $800 \mathrm{~mm}$ in the east (Conti, 1998). Some of these forests were severely affected by the last eruption of the PCCVC. This volcanic complex is located in the Southern zone of the Chilean Andes $\left(40.5^{\circ} \mathrm{S}, 72.2^{\circ} \mathrm{W}\right)$ and is one of the most active volcanic complexes in South America, eight eruptions having occurred in the twentieth century alone (González et al., 2014). Its most recent eruption occurred in 2011 and the complex remained active, with decreasing intensity, for almost a year. Tephra fall was the most widelyspread impact of the eruption. Pyroclastic material was distributed by the prevailing western winds over a vast area, especially in northern Argentinean Patagonia, its texture and thickness varying greatly within the fallout zone (Villarrosa and Outes, 2013; González et al., 2014; Swanson et al., 2016).

Table 1. Location and environmental characteristics of the two sites affected by tephra deposition after the eruption of the Puyehue-Cordón Caulle Volcanic Complex (PCCVC - Cardenal Samoré 1 and 2) and the unaffected site (Cerro Otto).

\begin{tabular}{|c|c|c|c|c|c|c|c|}
\hline Site & Latitude & Longitude & $\begin{array}{l}\text { Altitude } \\
\text { (m } \\
\text { a.s.l.) }\end{array}$ & $\begin{array}{l}\text { Annual } \\
\text { precipitation } \\
(\mathrm{mm})^{*}\end{array}$ & $\begin{array}{l}\text { Distance } \\
\text { to } \\
\text { PCCVC } \\
(\mathrm{km})\end{array}$ & $\begin{array}{l}\text { Tephra } \\
\text { layer } \\
\text { depth } \\
\text { (cm) }\end{array}$ & $\begin{array}{l}\text { Light } \\
\text { intensity } \\
\text { (lux)** }\end{array}$ \\
\hline Cardenal & $-40^{\circ}$ & $-71^{\circ}$ & 1156 & 3000 & 21.6 & $\sim 50$ & $12449 \pm$ \\
\hline $\begin{array}{l}\text { Samoré } \\
1\end{array}$ & $43.556^{\prime}$ & $55.504^{\prime}$ & & & & & $4126^{b}$ \\
\hline Cardenal & $-40^{\circ}$ & $-71^{\circ}$ & 1102 & 3000 & 16.5 & $\sim 50$ & $50957 \pm$ \\
\hline $\begin{array}{l}\text { Samoré } \\
2\end{array}$ & $41.571^{\prime}$ & $58.118^{\prime}$ & & & & & $10350^{\mathrm{a}}$ \\
\hline Cerro & $-41^{\circ}$ & $-71^{\circ}$ & 1144 & 800 & 90.5 & $\sim 1$ & $2684 \pm$ \\
\hline Otto & $8.673^{\prime}$ & $20.413^{\prime}$ & & & & & $1134^{\mathrm{c}}$ \\
\hline
\end{tabular}

* =According to Conti (1998), $* *=$ Values are expressed as mean \pm S.E. and different superscript letters denote significant statistical differences. 
Two study sites were located close to the international road "Cardenal Samoré" (Table 1, Figure 1), which connects Argentina and Chile. In this region a tephra layer of approximately $50 \mathrm{~cm}$ lay on the forest soil and $N$. pumilio seedlings were growing in the tephra. At one of the sites, located $21.6 \mathrm{~km}$ from the PCCVC, most of the adult trees remained alive after the tephra fall (Cardenal Samore $1=\mathrm{CS} 1$ ), while at the other site, $16.5 \mathrm{~km}$ from the PCCVC, a high proportion of trees (over 70\%) had died as a consequence of the volcanic eruption (Cardenal Samoré $2=\mathrm{CS} 2$ ). A third sampling site was situated on Cerro Otto, 94.6 $\mathrm{km}$ from the volcano, where the effect of the eruption was minimal and there was no tephra layer on the soil (Table 1, Figure 1). This site (Cerro Otto = $\mathrm{CO}$ ), in terms of tephra, was considered an unaffected site, with $N$. pumilio seedlings growing directly in the soil.

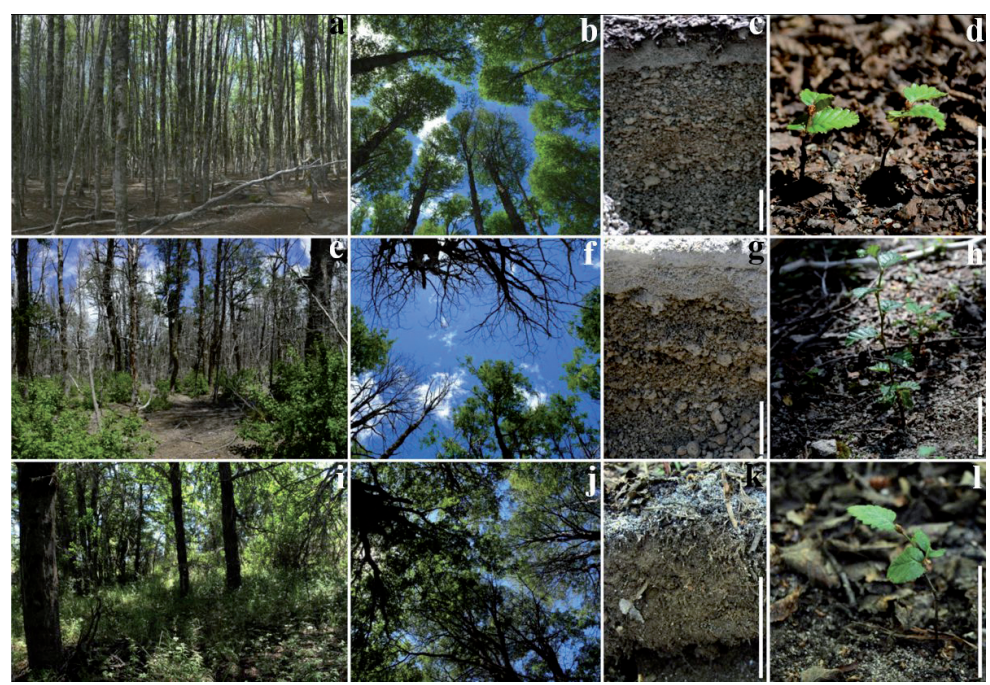

Figure 1. Environmental characteristics of the three sampling sites, two of which are affected by elevated tephra deposition after the PCCVC eruption (Cardenal Samoré $1=\mathbf{a}-\mathbf{d}$, Cardenal Samoré $2=\mathbf{e}-\mathbf{h}$ ) and the unaffected site $($ Cerro Otto $=\mathbf{i}-\mathbf{l})$. General structure of the forest $(\mathbf{a}, \mathbf{e}, \mathbf{i})$, canopy $(\mathbf{b}, \mathbf{f}, \mathbf{j})$, accumulation of tephra on the soil $(\mathbf{c}, \mathbf{g}$, $\mathbf{k}$; scale bars $=10 \mathrm{~cm})$ and size of the seedlings present at each site $(\mathbf{d}, \mathbf{h}, \mathbf{l}$; scale bars $=4 \mathrm{~cm})$.

At each of these three sites five 18-month-old seedlings were collected. These belonged to the first germination batch following the eruption. Seedlings were carefully removed from the substrate in order to preserve root systems and the surrounding substrate: tephra at both sites located in Cardenal Samoré (CS1 and CS2) and soil in the unaffected site (CO). The samples were wrapped in plastic bags and stored at $4{ }^{\circ} \mathrm{C}$ for no longer than a week, when further procedures were carried out.

\subsection{Evaluation of environmental factors and plant traits}

Luminous intensity was measured using a light meter (Extech 407026, FLIR Systems Inc.) held over each of the sampled seedlings, at the same time of day on three consecutive sunny days.

In order to evaluate physicochemical properties of the substrates (tephra or soil), samples were air dried up to constant weight. They were then sieved through a 
$2 \mathrm{~mm}$ mesh and mixed with deionized water for determination of $\mathrm{pH}(2: 5 \mathrm{w}: \mathrm{v})$ and conductivity (1:5 $\mathrm{w}: \mathrm{v})$ by means of a $\mathrm{pH}-$ meter and electric conductivity meter, respectively. Available $\mathrm{P}$ was determined in an extract of $\mathrm{NaHCO}_{3} 0.5 \mathrm{M}$ at pH 8.5 using the procedure described by Olsen and Sommers (1982). To determine bulk density a steel cylinder of $100 \mathrm{~mL}$ was filled with the substrate and dried in an air-forced oven at $65^{\circ} \mathrm{C}$ for $72 \mathrm{~h}$, then the substrate was weighed and the relation between weight and total soil volume was calculated. A portion of $30 \mathrm{~g}$ of dry substrate was added to $50 \mathrm{~mL}$ water, and after $24 \mathrm{~h}$ the final volume was calculated to obtain particle density. Total porosity was calculated as the relative difference between particle density and bulk density, expressed as a percentage (Van Reeuwijk, 1993).

To evaluate seedling development, the following morphometric measures were taken using a digital calliper $($ resolution $=0.1 \mathrm{~mm})$ : shoot, epicotyl and mainroot length; shoot, epicotyl and root collar diameter.

\subsection{Statistics}

One-way ANOVAs followed by Holm-Sidak post-hoc tests were used to compare the three sampling sites (CS1, CS2 and CO) for the following data: light inten sity, physicochemical substrate characteristics $(\mathrm{pH}$, conductivity, available $\mathrm{P}$, bulk density, particle density and porosity) and morphometric measures. Data not meeting ANOVA assumptions (epicotyl length and root diameter) were normalized using $\ln$ transformations before analyses, but the data are presented in their original scales of measurement. Finally, a Pearson Correlation Matrix and a Principal Component Analysis (PCA) for the different variables were performed. All statistical analyses were carried out using the IBM SPSS Statistics software v. 23 (IBM Corp.).

\section{Results}

Light intensity was higher in the forest with tephra deposition and the highest proportion of dead trees (CS2) than both the other sites. The other forest located in Cardenal Samoré (CS1) presented intermediate values and the unaffected site $(\mathrm{CO})$ the lowest luminous intensity (Table 1$)$ (CS2 vs. CS1, $\mathrm{p}=0.007$; CS2 vs. CO, $\mathrm{p}<0.001$; CS1 vs. $\mathrm{CO}, \mathrm{p}=$ 0.075). Differences in light intensity were directly related to tree cover (Figure 1). Significant differences were observed for most of the physicochemical substrate characteristics analysed (Table 2).

Table 2. Physicochemical characteristics of the substrates corresponding to the sites severely affected by the eruption (Cardenal Samoré 1 and 2) and the unaffected site (Cerro Otto).

\begin{tabular}{|c|c|c|c|c|c|c|}
\hline Site (type of substrate) & pH (in water) & $\begin{array}{l}\text { Conductivity } \\
(\mu \mathrm{S} / \mathrm{cm})\end{array}$ & $\begin{array}{l}\text { Available P } \\
(\mathrm{mg} / \mathrm{kg})\end{array}$ & $\begin{array}{l}\text { Particle } \\
\text { density }(g / m L)\end{array}$ & $\begin{array}{l}\text { Bulk density } \\
(\mathrm{g} / \mathrm{mL})\end{array}$ & Porosity (\%) \\
\hline $\begin{array}{l}\text { Cardenal Samoré } 1 \\
\text { (tephra) }\end{array}$ & $4.67 \pm 0.04^{b}$ & $96.41 \pm 0.21^{\mathrm{c}}$ & $18.34 \pm 2.32^{b}$ & $1.83 \pm 0.13^{\mathrm{a}}$ & $1.02 \pm 0.02^{b}$ & $44.0 \pm 4.11^{\mathrm{a}}$ \\
\hline $\begin{array}{l}\text { Cardenal Samoré } 2 \\
\text { (tephra) }\end{array}$ & $3.91 \pm 0.01^{\mathrm{c}}$ & $341.4 \pm 0.42^{b}$ & $48.35 \pm 6.38^{\mathrm{a}}$ & $1.93 \pm 0.08^{\mathrm{a}}$ & $1.07 \pm 0.01^{\mathrm{a}}$ & $44.2 \pm 1.58^{\mathrm{a}}$ \\
\hline Cerro Otto (soil) & $5.23 \pm 0.02^{\mathrm{a}}$ & $853 \pm 0.79^{\text {a }}$ & $16.73 \pm 0.41^{b}$ & $1.34 \pm 0.07^{\mathrm{b}}$ & $0.68 \pm 0.01^{\mathrm{c}}$ & $48.7 \pm 2.71^{\mathrm{a}}$ \\
\hline
\end{tabular}

Values are expressed as mean \pm S.E., different superscript letters denote significant statistical differences for each of the variables analysed. 
Conductivity and $\mathrm{pH}$ values were higher in the soil of the unaffected site (CO) than in the tephra of the two affected sites (CS1 and CS2), while available P was much higher in CS2 (with tephra and dead trees) than in the other two sites (CO and CS1), reaching 48 ppm of available P. Differences were also registered for both bulk and particle densities, which were higher in both sites with tephra (CS1 and CS2) than in the unaffected site (CO). However, porosity was similar for all the substrates analysed (Table 2).

Seedlings from CS2 had the highest values for all the measured diameters (shoot, epicotyl and root diameter), while those growing in CS1 and $\mathrm{CO}$ had similar values (Figure 2). Shoot and root lengths were similar for seedlings from CS2 and CO, and higher than the seedlings located in CS1, while epicotyl length was higher in CS2 than in the other two sites (Figure 2).
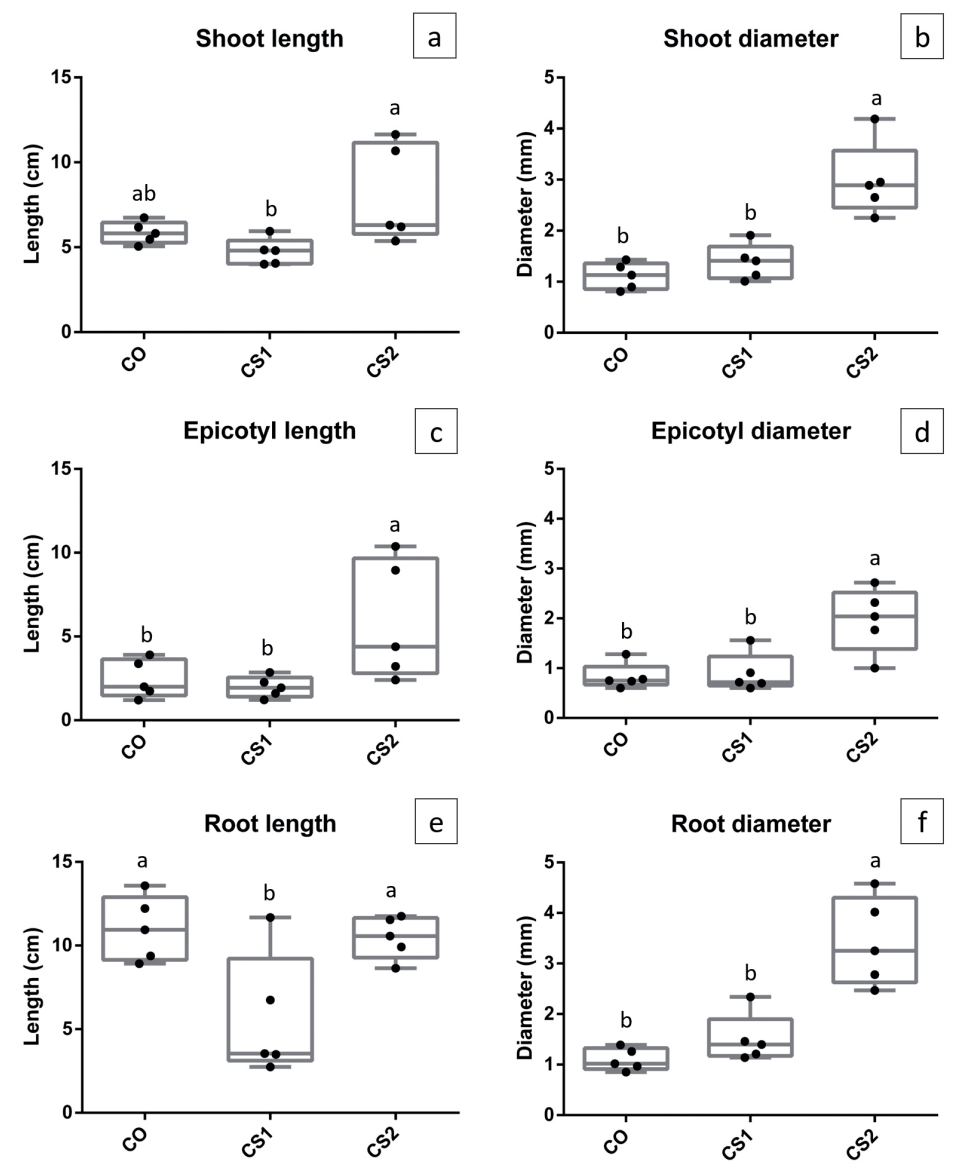

Figure 2. Morphometric measures registered in Nothofagus pumilio seedlings in the sites with tephra, Cardenal Samoré 1 (CS1) and Cardenal Samoré 2 (CS2); and in the unaffected site, Cerro Otto (CO). Shoot length (a) and diameter (b); epicotyl length (c) and diameter (d); root length (e) and diameter (f). In the boxplots: boxes represent the interquartile range and the line inside the boxes represents the median. Whiskers indicate the range of data. Different letters above the boxplots indicate differences between the study sites. 
According to the factorial analysis performed by means of principal component (PCA) extraction, the first two principal components explained $80.5 \%$ of total variance (Figure 3a). Shoot and root diameter and shoot length were highly correlated to available $\mathrm{P}$ and light intensity data (Table 3). Moreover, a strong positive relation was found between porosity and electric conductivity and these factors were negatively correlated to bulk density, while $\mathrm{pH}$ had a strong negative correlation with available $\mathrm{P}$ and bulk density. The individual seedlings were clearly separated into three distinct groups, which corresponded to their sampling sites of origin (Figure 3b). The different positions of the three sampling sites in the multivariate space were mainly explained by plant performance, available P and light intensity for CS2 (forest with tephra deposition and a high proportion of dead trees); and by $\mathrm{pH}$, porosity and conductivity for $\mathrm{CO}$ (unaffected site), while CS1 (forest with tephra where most adult trees remained alive after the eruption) was mostly characterized by low values of root and shoot length.
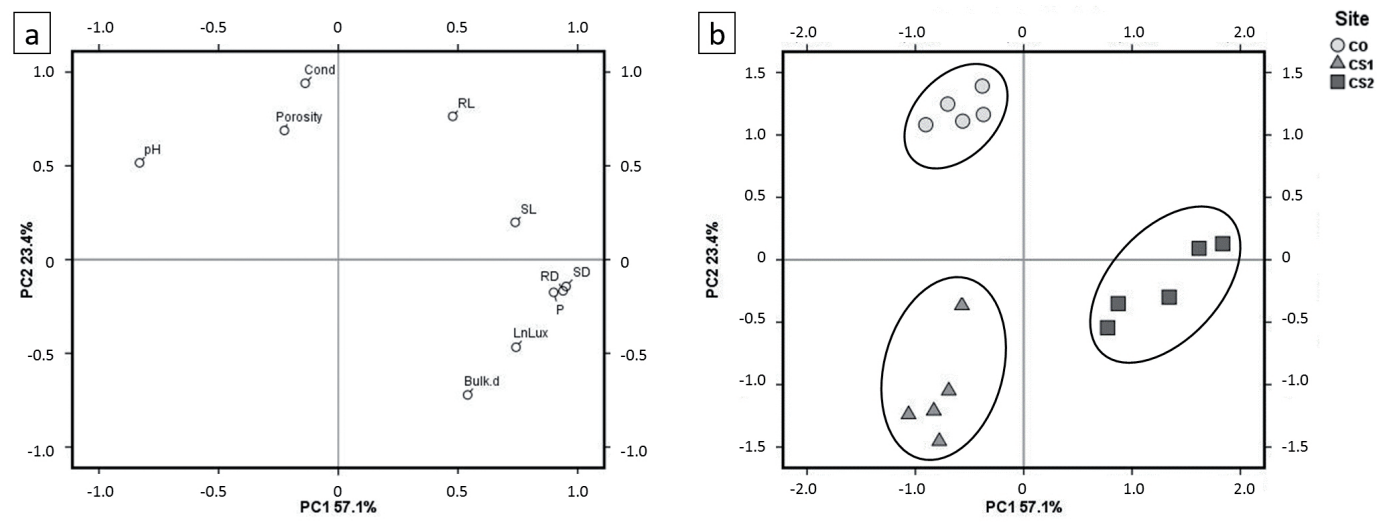

Figure 3. Principal component analysis (PCA) of the different morphological traits evaluated in Nothofagus pumilio seedlings (SL, RL: shoot and root length, respectively; SD, RD: shoot and root diameter, respectively) and the physicochemical characteristics determined for the substrates (Bulk.d: bulk density; Cond: conductivity). 
Table 3. Correlation matrix obtained for all the variables analysed at the three different sites studied after the eruption of the PCCVC (morphometric measures, light intensity and physicochemical properties of the substrate).

\begin{tabular}{|c|c|c|c|c|c|c|c|c|c|}
\hline Variables & pH & Cond. & Bulk.d & Porosity & $\mathbf{P}$ & SL & SD & RL & RD \\
\hline \multirow[t]{2}{*}{ Lux } & -0.831 & -0.448 & 0.577 & -0.690 & 0.793 & 0.405 & 0.733 & 0.031 & 0.698 \\
\hline & $* * *$ & * & $*$ & $* *$ & $* * *$ & ns & ** & ns & ** \\
\hline \multirow[t]{2}{*}{$\mathbf{P h}$} & & 0.592 & -0.858 & 0.483 & -0.897 & -0.469 & -0.835 & 0.000 & -0.852 \\
\hline & & $* *$ & $* * *$ & $* * *$ & $* * *$ & * & $* * *$ & ns & $* * *$ \\
\hline \multirow[t]{2}{*}{ Cond. } & & & -0.842 & 0.598 & -0.240 & 0.091 & -0.292 & 0.587 & -0.319 \\
\hline & & & $* * *$ & $* * *$ & ns & $\mathrm{ns}$ & $\mathrm{ns}$ & $*$ & ns \\
\hline \multirow[t]{2}{*}{ Bulk.d } & & & & -0.346 & 0.628 & 0.142 & 0.640 & -0.272 & 0.707 \\
\hline & & & & $\mathrm{ns}$ & ** & ns & ** & $\mathrm{ns}$ & ** \\
\hline \multirow[t]{2}{*}{ Porosity } & & & & & -0.258 & -0.237 & -0.286 & 0.372 & -0.178 \\
\hline & & & & & $\mathrm{ns}$ & $\mathrm{ns}$ & ns & ns & ns \\
\hline \multirow[t]{2}{*}{$\mathbf{P}$} & & & & & & 0.481 & 0.799 & 0.312 & 0.840 \\
\hline & & & & & & $*$ & $* * *$ & ns & $* * *$ \\
\hline \multirow[t]{2}{*}{ SL } & & & & & & & 0.688 & 0.370 & 0.627 \\
\hline & & & & & & & ** & ns & ** \\
\hline \multirow[t]{2}{*}{ SD } & & & & & & & & 0.331 & 0.967 \\
\hline & & & & & & & & ns & *** \\
\hline \multirow[t]{2}{*}{ RL } & & & & & & & & & 0.275 \\
\hline & & & & & & & & & ns \\
\hline
\end{tabular}

Lux: Light intensity, SL: Shoot length, SD: Shoot diameter, RL: Root length, RD: Root diameter, Cond.: Conductivity, Bulk.d: Bulk density.

Significance: $\mathrm{ns}=$ non-significant, ${ }^{*} p<0.05,{ }^{* *} p<0.01,{ }^{* * *} p<0.001$.

\section{Discussion}

In spite of the stressful environmental conditions that follow volcanic eruptions, such as thick tephra deposits, low soil nutrient content, instability of substrate surface, drought and changes in light dynamics, pioneer woody plants are able to become established relatively soon (Antos and Zobel, 2005; Obase et al., 2007). In this study our results showed that N. pumilio seedlings were able to grow on the thick tephra layer and survived for at least three years after the eruption, even though their root systems were not in contact with the buried forest soil (Figure 1, c and g). These results are in agreement with previous studies carried out in Patagonia, which reported that some native forest species, such as Araucaria araucana,
Austrocedrus chilensis and different Nothofagus species, are capable of colonizing and growing rapidly on tephra deposits (González et al., 2014), which in several cases can be helped by microbial interactions at soil-root level (Marín et al., 2016; 2017; Mestre et al., 2017). For example, 17 months after the eruption of Hudson volcano, Vogel (1996) described the massive establishment of $N$. pumilio seedlings growing directly on the tephra. However, their survival capacity was uncertain, most probably as a consequence of nutritional deficiencies, mainly N and P (González et al., 2014). Similar recolonization strategies were registered in some $N$. pumilio forests affected by the last eruption of the PCCVC (Grosfeld and Puntieri, 2013; Magnin et al., 2016; Montiel et al., 2016), but this should be observed in the long term to analyse 
effectively whether nutrient depletion could be a determinant factor limiting seedling establishment in this context.

Our results reveal that specimens located in the forest with thick tephra deposits and a high proportion of dead trees, which corresponded to the most severely affected study site (CS2), showed the highest values for all the morphometric variables analysed (Figure 2 ), in concordance with higher growing rates when compared with the other two sites. This behaviour is mainly related to the high light intensity received at soil surface level (Figure 1, Table 1) and the high available $\mathrm{P}$ of the tephra in this site. Nothofagus pumilio is characterized as a species with a regeneration strategy of "gap dynamics"; therefore, it usually germinates and grows slowly in the shaded understory for long periods, until the formation of a canopy gap allows greater light availability (Heinemann, 2007; Martínez Pastur et al., 2007).

In the most affected site of this study (CS2), because of low canopy coverage, light was not a limiting factor for seedling growth; this, together with the high level of available P determined the fast seedling development observed here. In mature Nothofagus forest, low $\mathrm{P}$ availability is a restrictive factor due to the high P-fixing capacity of volcanic soils (La Manna et al., 2011; Seguel et al., 2013; Cornejo et al., 2017), but most of the dominant plant species behaved as non-P-limited, probably due to a high percentage of mycorrhizal colonization (Diehl et al., 2008). High P availability in CS2 site could be due to the low $\mathrm{pH}$ of the tephra (Table 2), since $\mathrm{P}$ dissolution rate increases as $\mathrm{pH}$ decreases (Dahlgren et al., 2004). This behaviour can be due to a $\mathrm{pH}$ decrease by acid rain or $\mathrm{S}$ oxidation in the tephra as previously reported in other latitudes (Cronin et al., 1997). This acidification could be responsible for an increase of phytotoxic aluminun $\left(\mathrm{Al}^{3+}\right)$ which can explain the notorious increase of root diameter (Figure 2e) since the most important effect of the $\mathrm{Al}^{3+}$ phytotoxicity is the root thickening. Another important factor is that recently-deposited tephra contains a certain amount of $\mathrm{P}$ which is readily soluble in acid solutions (Shoji et al.,1993), and it has a low quantity of organic matter that can immobilize organic P (Borie and Rubio, 2003; Borie et al., 2010). This nutrient is particularly important for plant development and performance (Dahlgren et al., 2004), and its importance for $N$. pumilio growth was reflected through the Principal Component Analyses (PCA, Figure 3), which revealed it as the experimental variable most directly associated with shoot and root diameters. These results are in agreement with Magnin et al. (2016), who found that the length growth of the juvenile $N$. pumilio trees located close to the volcano (and affected by tephra deposition) increased significantly after the eruption, suggesting that the P released by leaching from the ash deposition could have induced an increase in the growth of terrestrial plants. In contrast, seedlings from site CS1 presented the lowest values in almost all the morphometric measures, possibly due the combination of the same two factors in an unfavourable way: low luminous intensity and lower P availability (Figure 3), reinforcing the high importance of both environmental factors in the $N$. pumilio seedling growth (Heinemann, 2007; Martínez Pastur et al., 2007). Considering a preliminary methodological analysis, and based on our results, shoot and root diameter seem to be better indicators of seedling response to the different environmental factors analyzed than shoot and root length, also evidenced by means of PCA (Figure 3a).

In this work we focused on N. pumilio seedlings after the PCCVC eruption, and environmental factors that could influence their growth. Nothofagus pumilio is an interesting species and a good study model, not only because of its economic and ecological importance, but also because it occupies vast areas of the Andean-Patagonian native forests in the southern 
region of Argentina and Chile, one of the most active volcanic areas worldwide.

\section{Conclusions}

Our results highlight the regeneration capacity of native $N$. pumilio forests after a volcanic eruption, which represents a major geological disturbance. In this context, the ability of $N$. pumilio seedlings to become successfully established and develop directly in the tephra deposits in forests severely affected by the eruption is noteworthy, their development being related principally to light intensity and available $\mathrm{P}$. It is noticeable that seedling growth is influenced by several factors that should also be considered during the regeneration process and subsequent succession, such as fungal communities associated with their root systems. In this sense, volcanic eruptions provide an exceptional opportunity to study different processes in dynamic landscapes, such as the principal factors determining recruitment of pioneer plant species. This is a temporally unique and essential study; therefore, long-term research is necessary in order to understand interactions between factors following large-scale disturbances. These results will contribute to improving cultivation strategies for native forestry species, and to the design of restoration activities in different affected environments.

\section{Acknowledgements.}

We are grateful to Mr. Jorge Puga and Lic. Pablo Albear for collaborating in the sampling, to Lic. Ayelen Carron, Lic. Juan Eizaguirre, Lic. Rubí Duo Saito and Dr. Marina Stecconi for their helpful collaboration. We also thank BSc. (Hons) Audrey Urquhart for language revision and to National Park Administration for giving us permission to work in a protected area (Permission $\left.N^{\circ} 1280 / 17\right)$. Financial support for this work was provided by grants: B200 (UNComahue), PICT2014-1459 (FONCyT), PIA14081 (Programa de Sustentabilidad y Competitividad Forestal, BID 2853/ OC-AR) and the binational Project CH/13/01-PCCI130008 MINCyT (Argentina)-CONICYT (Chile). Lic. D. Moguilevsky was supported by a CONICET Ph.D. fellowship.

\section{References}

Antos, J.A., and Zobel, D.B. (2005). Plant responses in forests of the tephra-fall zone. In V. H. Dale, C. M. Swanson and C. M. Crisafulli (Eds.), Ecological responses to the 1980 eruption of Mt. St. Helens (pp. 3-11). Springer-Verlag, USA.

Borie, F. and Rubio, R. (2003). Total and organic phosphorus in Chilean volcanic soils. Gayana Botánica 60:69-78.

Borie, F., Rubio, R., Morales, A., Curaqueo, G., and Cornejo, P. (2010). Arbuscular mycorrhizae in agricultural and forest ecosystems in Chile. Journal of Soil Science and Plant Nutrition, 10(3), 185206.

Conti, H. A. (1998). Características climáticas de la Patagonia. Flora Patagónica, 8, 31-47.

Cornejo, P., Seguel, A., Aguilera, P., Meier, S., Larsen, J. and Borie, F. (2017). Arbuscular Mycorrhizal Fungi Improve Tolerance of Agricultural Plants to Cope Abiotic Stress Conditions. In: Plant-Microbe Interactions in Agro-Ecological Perspectives. Springer, Singapore, pp: 55-80.

Cremona, M. V., Ferrari, J., and López, S. (2011). Las cenizas volcánicas y los suelos de la región. Revista Presencia, 57, 8-11.

Cronin, S. J., Hedley, M. J., Smith, R.G., and Neall V. E. (2010) Impact of Ruapehu ash fall on soil and pasture nutrient status 1. October 1995 eruptions. 
New Zealand Journal of Agricultural Research, 40, 383-395.

Dahlgren, R. A., Saigusa, M., and Ugolini, F. C. (2004). The nature, properties and management of volcanic soils. Advances in Agronomy, 82, 113-182.

Dale, V. H., Swanson, C. M., and Crisafulli C. M. (2005). Disturbance, survival and succession: understanding ecological responses to the 1980 eruption of Mt. St. Helens. In V. H. Dale, C. M. Swanson and C. M. Crisafulli (Eds.), Ecological responses to the 1980 eruption of Mt. St. Helens (pp. 3-11). Springer-Verlag, USA.

Diehl, P., Mazzarino, M. J., and Fontenla, S. (2008). Plant limiting nutrients in Andean-Patagonian woody species: effects of interannual rainfall variation, soil fertility and mycorrhizal infection. Forest Ecology and Management, 255(7), 29732980.

Ferreiro, N., Satti, P., Orden, L., and Mazzarino, M. J. (2015). Estadios de sucesión temprana en la ceniza volcánica depositada por el evento volcánico Puyehue-Cordón Caulle de 2011 en el camino "De los Siete Lagos" (Norpatagonia). IV CONEBIOS, Esquel, Argentina.

Ghermandi L., González, S., Franzese, J., and Oddi, F. (2015). Effects of volcanic ash deposition on the early recovery of gap vegetation in Northwestern Patagonian steppes. Journal of Arid Environments, 122, 154-160.

González, M. E., Amoroso, M., Lara, A., Veblen, T. T., Donoso, C., Kitzberger, T., Mundo, I. and Promis, A. (2014). Ecología de disturbios y su influencia en los bosques templados de Chile y Argentina. In C. Donoso, M. E. González and A. Lara (Eds.), Ecología Forestal. Ediciones Universidad Austral de Chile, Chile. (pp. 411-502)
González, M. E., Donoso, C. Z., Ovalle, P., and Martínez-Pasteur, G. (2006). Nothofagus pumilio (Poep. Et Endl) Krasser. In C. Z. Donoso (Ed.), Las especies arbóreas de los bosques templados de Chile y Argentina. Autoecología (pp. 486-500). Marisa Cuneo Ediciones, Chile.

Grosfeld, J., and Puntieri, J. (2013). Evaluación de daños y monitoreo de la vegetación tras la erupción del Complejo volcánico Cordón Caulle de junio 2011. In Legislatura de Neuquén and Centro Regional Universitario Bariloche (Eds.), Efectos de la caída de cenizas del Complejo Volcánico Puyehue (CPCC) sobre la región del lago Nahuel Huapi. Informe Final. Universidad Nacional del Comahue. (pp. 61-73).

Heinemann, K. (2007). Aspectos espaciales y temporales del establecimiento de Nothofagus pumilio en claros de bosques maduros en los extremos de un gradiente ambiental en el Noroeste de la Patagonia. $\mathrm{PhD}$ thesis, Universidad Nacional del Comahue, Bariloche. 142p.

La Manna, Buduba, L., Irisarri, C., Ferrari, J., and Cremona, M. V. (2011). Los nutrientes del suelo en la región andino patagónica: una aproximación a la interpretación de datos analíticos. Patagonia Forestal, Esquel, 7-8.

Magnin, A., Villalba, R., Torres, C. D., Stecconi, M., Passo, A., Sosa, C. M., and Puntieri, J. G. (2017). Effect of volcanic ash deposition on length and radial growths of a deciduous montane tree (Nothofagus pumilio). Austral Ecology, 42(1), 103-112.

Marín, C., Aguilera, P., Cornejo, P., Godoy, R., Oehl, F., Palfner, G., Boy, J. (2016). Arbuscular mycorrhizal assemblages along contrasting Andean forests of Southern Chile. Journal of Soil Science and Plant Nutrition, 16, 916-929. 
Martínez-Pastur, G., Lencinas, M.V., Peri, P. L., Arena, M. (2007). Photosynthetic plasticity of Nothofagus pumilio seedlings to light intensity and soil moisture. Forest Ecology and Management, 243, 274-282.

Mazzarino, M. J., Gobbi, M. E. (2005). Indicadores de circulación de nutrientes en bosques AndinoPatagónicos. Ediciones INTA. IDIA XXI, 5, 1518.

Mestre, M.C., Pastorino, M.J., Aparicio, A.G., Fontenla, S.B. (2017). Natives helping foreigners? The effect of inoculation of poplar with patagonian beneficial microorganisms. Journal of Soil Science and Plant Nutrition, 17, 1028-1039.

Montiel, M., González, M. E., Crisafulli, C. M. (2016). Caída de tefra y su influencia sobre la estructura y dinámica de los bosques andinos de Nothofagus en el Parque Nacional Puyehue, Chile. In: Anales del Instituto de la Patagonia. Universidad de Magallanes. 44, 5-11.

Obase, K., Tamai, Y., Yajima, T., Miyamoto, T. (2007). Morphological characteristics of ectomycorrhizas found in Willow and Poplar seedlings established in the area devastated by the volcanic eruption of Mt. Usu, Hokkaido, Japan in 2000. Eurasian Journal of Forest Research, 10, 173-178.

Olsen, S. R., Sommers, L.E. (1982). Determination of available phosphorus. In A.L. Page., R.H. Miller., D.R. Keeney (eds.). Method of Soil Analysis, vol. 2. 403. Madison, WI. American Society of Agronomy.

Rebertus, A.J., Veblen, T.T. (1993) Structure and treefall gap dynamics of old-growth Nothofagus forests in Tierra del Fuego, Argentina. Journal of Vegetation Science, 4, 641-654.

Satti, P., Mazzarino, M. J., Roselli, L., Crego, P. (2007). Factors affecting soil $P$ dynamics in temperate volcanic soils of southern Argentina. Geoderma, 139(1-2), 229-240.
Seguel, A., Cumming, J.R., Klugh-Stewart, K., Cornejo, P., Borie, F. (2013). The role of arbuscular mycorrhizas in decreasing aluminium phytotoxicity in acidic soils: a review. Mycorrhiza, 23(3), 167-183.

Shoji, S., Nanzyo, M., Dahlgren, R. (1993). Productivity and utilization of volcanic ash soils. Developments in Soil Science, 21, 209-251.

Swanson, F.J., Major, J.J. (2005). Physical environments, events, and geological-ecological interactions at Mount St. Helens. In V. H. Dale, C. M. Swanson and C.M. Crisafulli (Eds.), Ecological responses to the 1980 eruption of Mt. St. Helens Springer-Verlag, USA. (pp. 27-44).

Swanson, F.J., Jones, J., Crisafulli, C., González, M.E., Lara, A. (2016). Puyehue-Cordón Caulle eruption of 2011: tephra fall and initial forest responses in the Chilean Andes. Bosque, 37, 85-96.

Van Reeuwijk, L.P. (1993). Procedures for Soil Analysis. 4th ed. International Soil Reference and Information Centre, Wageningen, The Netherlands.

Villarosa, G., Outes, V. (2013). La erupción del Cordón Caulle del 4 de junio de 2011: Mapa de distribución, características de la ceniza volcánica caída en la región e impactos en la comunidad. In Legislatura de Neuquén and Centro Regional Universitario Bariloche (Eds.), Efectos de la caída de cenizas del Complejo Volcánico Puyehue (CPCC) sobre la región del lago Nahuel Huapi. Informe Final. Universidad Nacional del Comahue. (pp. 15-53).

Vogel, A. (1996). Beobachtungen zur Regeneration der Vegetation nach Ascheeruption am HudsonVulkan im südlichen Chile. In: Holtmeier, F.K. (Ed.), Beiträge aus den Arbeitsgebieten am Institut für Landschaftsökologie. (pp. 3-11). 